\title{
Ankylosing Spondylitis in Sub-Saharan Africa: A Series of 48 Cases Reported in Burkina Faso (West Africa)
}

\section{Zabsonre Tiendrebeogo Wendlassida Joelle1,2*, Sawadogo Serge Aime ${ }^{2,3}$, Kabore Fulgence1, Ilboudo Alain', Sougue Charles' ${ }^{1}$, Zongo Enselme1, Sompougdou Camille1, Ouédraogo Moussa1, Tiendrebeogo Evariste ${ }^{1}$, Ouedraogo Dieu-Donne ${ }^{1,2}$}

\author{
${ }^{1}$ Rheumatology Department, Bogodogo District Hospital, Ouagadougou, Burkina Faso \\ ${ }^{2}$ Université Ouaga I Pr Joseph Ki-Zerbo, Ouagadougou, Burkina Faso \\ ${ }^{3}$ Department of Basic and Mixed Sciences, Université Ouaga I Pr Joseph Ki-Zerbo, Ouagadougou, Burkina Faso \\ Email: ${ }^{\star t}$ joelle@hotmail.com
}

How to cite this paper: Joelle, Z.T.W., Aime, S.S., Fulgence, K., Alain, I., Charles, S., Enselme, Z., Camille, S., Moussa, O., Evariste, T. and Dieu-Donne, O. (2018) Ankylosing Spondylitis in Sub-Saharan Africa: A Series of 48 Cases Reported in Burkina Faso (West Africa). Open Journal of Rheumatology and Autoimmune Diseases, 8, 87-92.

https://doi.org/10.4236/ojra.2018.83009

Received: July 16, 2018

Accepted: August 20, 2018

Published: August 23, 2018

Copyright $\odot 2018$ by authors and Scientific Research Publishing Inc. This work is licensed under the Creative Commons Attribution International License (CC BY 4.0).

http://creativecommons.org/licenses/by/4.0/

\begin{abstract}
Background: Ankylosing spondylitis is rare in sub-Saharan Africa. The purpose of our study was to report cases of AS in a black African population and to see the influence of gender. Method: It was a retrospective study conducted in the Rheumatology Department of Ouagadougou University Hospital, Ouagadougou, from March 2006 to February 28, 2015 for a period of nine years. All the patients who went under a rheumatology consultation during the study period were included. Patients with AS defined by the modified New York criteria were selected. Result: Forty-eight $(0.61 \%)$ cases of AS were diagnosed among 7806 patients received in the rheumatology department during the study period. The search for the HLA B27 antigen in 20 patients was positive in $11(55 \%)$. Half of the patients $(50 \%)$ had a BASDAI score $\geq 4$. Sacroiliitis was observed in all patients; it was stage 4 in 8 patients. Comparing by sex, there was no statistically significant difference by gender. Conclusion: Prevalence of ankylosing spondylitis increases. The presentation is similar to that of the caucasian series.
\end{abstract}

\section{Keywords}

Ankylosing Spondylitis, Black, African, Gender

\section{Background}

Ankylosing spondylitis is rare in sub-Saharan Africa. In 1993, Mijiyawa et al. reported 13 cases $(0.5 \%)$ recruited in three years among 2626 rheumatologic 
patients and highlighted the rarity of the HLA B 27 antigen [1]. Indeed, among the eight patients explored by Lopez-Larrea at Togo, ankylosing spondylitis (AS) was rather associated with B14 ${ }^{\star} 03$ antigen; B27 antigen was found in only one patient [2].

Studies from Burkina Faso reported a hospital frequency of $0.9 \%$ and their association in 55\% with HLA B27 antigen and HLA B * 27:05 alleles (50\% vs $3.7 \%$ of healthy controls, $P=0.001$, OR $=26$ ) [3] [4].

Ankylosing spondylitis does not seem so rare in Burkina Faso, unlike some neighboring countries (Côte d'Ivoire, Togo, Benin); unpublished series are reported in Mali and Niger, mainland countries like Burkina Faso with common ethnic groups. The clinical feature of AS in black African patients seems to be the rarity of extra-articular manifestations [5].

The aim of this work was to describe clinical and paraclinical features of ankylosing spondylitis and to pinpoint gender specificities in an African black population.

\section{Methods}

It was a retrospective study conducted in the Rheumatology Department of Ouagadougou University Hospital, Ouagadougou, from March 2006 to February 28,2015 for a period of nine years. All the patients who went under a rheumatology consultation during the study period were included; 13 patients in this series have already been published [3].

All had a complete clinical examination by a senior rheumatologist. The search for uveitis, enterocolopathy and psoriasis lesions has been systematic. Radiography of the cervical spine, thoracolumbar spine, pelvis and feet were systematic to all patients with axial pain or talalgy.

Patients with AS defined by the modified New York criteria were selected [6]; patients with any other spondyloarthropathy (reactive arthritis, HIV-associated arthritis, psoriatic arthritis or indeterminate spondyloarthropathies) were excluded. The serology of the human immunodeficiency virus was negative in all patients.

The data were collected using a pre-computerized individual file containing socio-demographic parameters (age, gender, profession), functional signs (seat of pain), disease duration, physical examination data, algo-functional indices (visual analog scale (VAS), Bath Ankylosing Spondylitis Disease Activity Index (BASDAI) and Bath Ankylosing Spondylitis Functional Index (BASFI)) [7] and the radiographic examinations. Cardiac ultrasound for aortic insufficiency has not been performed. All patients had an ophthalmic consultation.

The search for HLA-B27 molecules carried out in Paris (France) was obtained by incubating the lymphocytes with an anti-HLA-B27 antibody, the intensity of the fluorescence being measured by flow cytometry. In case of ambiguity, typing by molecular biology has been carried out. Anonymat and confidentiality of patients was respected. The data has been entered on the sphinx plus 2 software 
version 5 (5.1.0.2). The results were analyzed on SPSS 22 and processed in Excel 2007. Chi square test and student test were used for the statistical analysis, with a significance level of $5 \%$.

\section{Results}

Forty-eight $(0.61 \%)$ cases of AS were diagnosed among 7806 patients received in the rheumatology department during the study period. It was 35 male (72.9\%) and 13 female (27.1\%).

The mean age of patients at the disease onset was $30.10 \pm 12.64$ with extremes of 11 and 59 years. The mean duration of disease was $7.04 \pm 8.15$ years with extremes of 6 months and 40 years. This mean duration was 7.83 years \pm 8.98 years for male and 4.92 years \pm 5 years for female $(\mathrm{P}=0.1501)$.

The mean pain intensity, on a 10 -point VAS, was $5.9 \pm 1.8$. The mean BASDAI score was $4.3 \pm 1.5$ on a scale of 10 with extremes of 1.8 and 8.6. Half of the patients (50\%) had a BASDAI score $\geq 4$. The mean BASFI score was $3.5 \pm 2.4$ on a scale of 10 , with extremes of 0 and 10 . Twenty (41.7\%) with a BASFI score $\geq 4$.

Table 1 shows the distribution of patients according to clinical and radiological features. The clinical presentation does not differ according to gender $(\mathrm{p} \geq$ 0.05). Table 2 shows the distribution of patients by gender.

The search for the HLA B27 antigen in 20 patients was positive in 11 (55\%).

\section{Discussion}

The hospital frequency of the SA was $0.61 \%$ in our series. There were no clinical differences by gender. Extra-articular manifestations were rare.

A systematic review of the literature confirmed the low prevalence of AS in Africa [8]; it was estimated to 7.4 cases per 10,000 inhabitants in Africa, lower than in Europe (23.8), North America (31.9) and Asia (16.7). Our series of 48 cases is, to our knowledge, the largest reported in both West and Central Africa. The rarity of AS in sub-Saharan Africa seems to be related to the scarcity of HLA B27 antigen. HLA-B 14:03 is evoked as possibly associated with the black African SA [5]. Indeed, this allele was found in 4 among the 8 SA patients seen in Togo and among any control and in 2 of the 3 SA patients seen in Zambia [2] [9]. In Burkina Faso, only 2 of 14 SA were carriers of this allele, which was not found among the 27 controls [4]. HLA B * 27:05 was reported, however, in 50\% of AS against $3.7 \%$ of controls. In this series, the search for HLA B27 antigen in 20 patients was positive in $11(55 \%)$ confirming the association of HLA B27 antigen with AS in Burkina Faso. Unpublished cases of AS are reported in Mali and Niger, particularly in nomadic Fulani populations found mainly in the inland of West Africa. In Burkina Faso, SA seems to be more frequent among the Fulani and the Mossi ethnic group. But this impression must be confirmed by studies. The disparity of the disease on the continent could be linked to the ethnic and therefore genetic diversity of the populations that populate this part of the world. 
Table 1. Distribution of patients according to clinical and radiological features.

\begin{tabular}{|c|c|c|c|c|}
\hline & & & Number & $(\%)$ \\
\hline \multicolumn{5}{|l|}{ Clinical signs } \\
\hline & Chest pain & & 5 & $(10.4)$ \\
\hline & Back pain & & 44 & $(91.6)$ \\
\hline & & cervical & 2 & $(4.1)$ \\
\hline & & thoracolumbar & 4 & $(8.3)$ \\
\hline & & lumbar & 19 & $(39.5)$ \\
\hline & & Cervical and lumbar & 3 & $(6.2)$ \\
\hline & & Cervico-thoraco-lumbar & 16 & $(33.3)$ \\
\hline & Major painful joints & & 37 & $(77)$ \\
\hline & & hip & 21 & $(43.7)$ \\
\hline & & knee & 16 & $(33.3)$ \\
\hline & Buttocks pain & & 5 & $(10.4)$ \\
\hline & Talalgy & & 16 & $(33.3)$ \\
\hline & & Achilles tendon & 15 & $(31.2)$ \\
\hline & & plantar & 1 & (2) \\
\hline & Eye damage & & 5 & $(10.4)$ \\
\hline & & Uveitis & 4 & $(8.3)$ \\
\hline & & conjunctivitis & 1 & $(2)$ \\
\hline \multicolumn{5}{|l|}{ Radiologicalsigns } \\
\hline & syndesmophytes & & 20 & $(41.6)$ \\
\hline & coxitis & & 9 & $(18.7)$ \\
\hline & sacroiliitis & & & \\
\hline & & Stage $0-1$ & 6 & $(12.5)$ \\
\hline & & Stage 2 & 22 & $(45.8)$ \\
\hline & & Stage 3 & 12 & $(25)$ \\
\hline & & Stage 4 & 8 & $(16.6)$ \\
\hline
\end{tabular}

Table 2. Distribution of patients by gender.

\begin{tabular}{cccc}
\hline & Male $\mathrm{n}^{*}=35$ & Female $\mathrm{n}=13$ & Probability \\
\hline Age of the onset (years) & 28.91 & 33.31 & 0.2171 \\
Age of consulting (years) & 36.74 & 38.15 & 0.6963 \\
Disease duration (years) & 7.83 & 4.92 & 0.1501 \\
C7-wall $(\mathrm{cm})$ & 7.26 & 7.15 & 0.8996 \\
Nape-wall $(\mathrm{cm})$ & 2.71 & 2.15 & 0.754 \\
Schöber index $(10+($ en cm) & 3.03 & 3.38 & 0.2898 \\
VAS** $(/ 100 \mathrm{~mm})$ & 59.43 & 59.62 & 0.925 \\
BASDAI $^{* * *}(/ 10)$ & 4.28 & 4.35 & 0.851 \\
BASFI $^{* * *}(/ 10)$ & 3.47 & 3.55 & 0.8749 \\
\hline
\end{tabular}

${ }^{*}$ n: number; ${ }^{*}$ VAS: visual analog scale; ${ }^{* *}$ BASDAI: Bath Ankylosing Spondylitis Disease Activity Index;

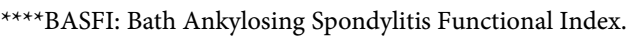


The clinical presentation of the disease is similar to that of the Caucasian subject [5]; however, extra-articular manifestations seem rare [10]. There was no statistically significant difference by gender. Our results are similar to those of Kilic who did not note any difference between the men's and women's SPA apart from the activity according to the sedimentation rate [11]. Overall, male patients seemed younger, had longer diagnostic delay, lower disease activity, worse spinal mobility, better quality of life, and more severe radiologic damage without statistically significant difference. In primary AS, there was a marked male predominance (76.2\%). However, Landi found that there are some differences in clinical and radiological manifestations, men showing more structural damage, whereas women more active disease [12].

\section{Conclusion}

Although present in Burkina Faso, SA remains rare. It is more often associated with HLA B27 with more less extra-articular manifestations. A study about the prevalence of B27 antigen in population and ethnic groups is needed.

\section{Author Contributions}

All the authors were involved in drafting the article or revising it critically for important intellectual content and approved the final version for publication.

\section{Conflicts of Interest}

The authors declare no conflicts of interest regarding the publication of this paper.

\section{References}

[1] Mijiyawa, M. (1993) Ankylosing Spondylitis in Togolese Patients. Medecine Tropicale, 53, 185-189.

[2] Lopez-Larrea, C., Mijiyawa, M., Gonzalez, S., Fernadez-Morera, J.L., Blanco-Gelaz, M.A., Martinez-Borra, J. and Lopez-Vaquez, A. (2002) Association of Ankylosing Spondylitis with HLA-B`1403 in West African Population. Arthritis \& Rheumatism, 46, 2968-2971. https://doi.org/10.1002/art.10584

[3] Ouédraogo, D.D., Tiéno, H., Kabore, H., Palazzo, E., Meyer, O. and Drabo, J.Y. (2009) Ankylosing Spondylitis in Rheumatology Patients in Ouagadougou (Burkina Faso). Clinical Rheumatology, 28, 1375-1377. https://doi.org/10.1007/s10067-009-1250-8

[4] Díaz-Peña, R., Ouédraogo, D.D., López-Vázquez, A., Sawadogo, S.A. and López-Larrea, C. (2012) Ankylosing Spondylitis in Three Sub-Saharan Populations: HLA-B ${ }^{\star} 27$ and HLA-B ${ }^{\star} 14$ Contribution. Tissue Antigens, 80, 14-15. https://doi.org/10.1111/j.1399-0039.2012.01879.x

[5] Tikly, M., Njobvu, P. and McGill, P. (2014) Spondyloarthritis in Sub-Saharan Africa. Current Rheumatology Reports, 16, 421. https://doi.org/10.1007/s11926-014-0421-z

[6] Van Dert Linden, S.M., Valkenburg, H.A. and Cats, A. (1984) Evaluation of Diagnostic Criteria for Ankylosing Spondylitis: A Proposal for Modification of the New 
York Criteria. Arthritis \& Rheumatism, 27, 361-368.

https://doi.org/10.1002/art.1780270401

[7] Garrett, S., Jenkinson, T. and Kennedy, L.G. (1994) A New Approach to Defining Disease Status in Ankylosing Spondylitis: The Bath Ankylosing Spondylitis Disease Activity Index. The Journal of Rheumatology, 21, 2286-2291.

[8] Dean, L.E., Jones, G.T., MacDonald, A.G., Downham, C., Sturrock, R.D., and Macfarlane, G.J. (2014) Global Prevalence of Ankylosing Spondylitis. Rheumatology (Oxford), 53, 650-657. https://doi.org/10.1093/rheumatology/ket387

[9] Díaz-Peña, R., Blanco-Gelaz, M.A., Njobvu, P., López-Vazquez, A., Suárez-Alvarez, B. and López-Larrea, C. (2008) Influence of HLA-B ${ }^{\star} 5703$ and HLA-B ${ }^{\star} 1403$ on Susceptibility to Spondyloarthropathies in the Zambian Population. The Journal of Rheumatology, 35, 2236-2240. https://doi.org/10.3899/jrheum.080395

[10] Belachew, D.A., Sandu, N., Schaller, B. and Guta, Z. (2009) Ankylosing Spondylitis in Sub-Saharan Africa. Postgraduate Medical Journal, 85, 353-357. https://doi.org/10.1136/pgmj.2007.064717

[11] Kilic, G., Kilic, E. and Ozgocmen, S. (2017) Is There Any Gender-Specific Difference in the Cut-Off Values of Ankylosing Spondylitis Disease Activity Score in Patients with Axial Spondyloarthritis? International Journal of Rheumatic Diseases, 20, 1201-1211. https://doi.org/10.1111/1756-185X.12885

[12] Landi, M., Maldonado-Ficco, H., Perez-Alamino, R., Maldonado-Cocco, J.A., Citera, G., Arturi, P., Sampaio-Barros, P.D., Flores Alvarado, D.E., Burgos-Vargas, R., Santos, E., Palleiro, D., Gutiérrez, M.A., Vieira-Sousa, E., Pimentel-Santos, F., Paira, S.O., Berman, A., Barrezueta, C.V., Vazquez-Mellado, J. and Collantes-Estevez, E. (2016) Gender Differences among Patients with Primary Ankylosing Spondylitis and Spondylitis Associated with Psoriasis and Inflammatory Bowel Disease in an Iberoamerican Spondyloarthritis Cohort. Medicine (Baltimore), 95, e5652.

https://doi.org/10.1097/MD.0000000000005652 